\title{
Conceptual realism and imperial nostalgia in Chinese legal historiography
}

\author{
Lucas Brang*
}

Forthcoming in the International Journal of Constitutional Law, Vol. 19, Issue 1, 2021

[Link to advance article: https://academic.oup.com/icon/advance-article-

abstract/doi/10.1093/icon/moab012/6257797]

Gao Quanxi, Zhang Wei \& Tian Feilong. Xiandai zhongguo de fazhi zhi lu [The Road to the Rule of Law in Modern China]. Beijing: Shehui kexue wenxian chubanshe [Social Sciences Academic Press China], 2012. Pp. 344. CN¥ 39. ISBN: 9787509729199.

Zhang Yongle. Jiu bang xin zao: 1911-1917 [The Remaking of an Old Country: 1911-1917]. Beijing: Beijing daxue chubanshe [Peking University Press]. 2d rev’d ed., 2016. Pp. 293. CN¥ 45. ISBN: 9787301274286.

In Chinese constitutional debates of the past decade, two intellectual trends stand out. The first we might call a turn toward "conceptual realism." Its implications are twofold: First, rather than lamenting the ostensible failure of political reality to live up to liberal constitutional precepts, this liberal conception itself should be revised. A kind of semantic coping strategy, this entails the more or less radical de-formalization of the term "constitution." Any constitution worthy of its name, then, must speak to the ineluctable facts of "real politics," however discouraging they may seem-auctoritas non veritas facit legem. Second, this "effective" or "living" constitution ought to be the sole conceptual benchmark for jurisprudential debates, lest the organic partystate be "corrupted" by a false legal formalism. Since the mid-2000s, prominent Chinese jurists have thus come to endorse a concept of constitution that refers not to a particular piece of legislation or written document, but rather a set of foundational institutions and political decisions which supposedly uphold the body politic and express its juridical will. ${ }^{1}$

\footnotetext{
${ }^{*}$ University of Cologne, Germany, and Chinese University of Hong Kong. Email: lbrang@smail.uni-koeln.de. I would like to thank Ryan Mitchell, Samuli Seppänen, Philipp Renninger, and Felix Wemheuer for their comments on the draft and Wang Jing for her logistic help with acquiring Chinese texts. The views expressed here are my own.

${ }^{1}$ See, e.g., Su Li, Dangdai zhongguo de zhongyang yu difang fenquan: chongdu Mao Zedong "lun shida guanxi” diwu jie [The Central-Local Separation of Powers in Contemporary China: Revisiting Chapter Five of Mao Zedong's On the Ten Major Relationships], 2 ZhongGuo Shehui KeXue [Soc. SCI. IN CHINA] 42 (2004); Chen
} 
Underlying all this has been a second, and perhaps more deep-seated shift, which is sometimes described as a turn toward "historicism." Like its nineteenth-century German counterpart, Chinese historicism comes with a rich vocabulary of particularism, a nativist belief in the exceptionality of national consciousness and its political form, and a self-heroizing language of resistance to the "homogenizing" effects of institutional convergence and universal values. ${ }^{2}$ In legal discourse, this nativism is further reinforced by an overriding concern for the fate of state sovereignty in the post-Cold War world. ${ }^{3}$ The veritable burst of Chinese interest in Carl Schmitt provides abundant intellectual fodder for this neo-statism. ${ }^{4}$ Equally disconcerting seems the mounting sense of imperial nostalgia to which the above trends lend themselves. This cannot be explained away as a mere penchant for tradition or the innocuous antiquarianism of an increasingly self-assured intelligentsia. Rather, China's imperial past also serves as a theoretical background against which the political exigencies of its present rise are debated. ${ }^{5}$

Such is the intellectual context in which the two books that are the focus of the present review essay were produced. Certainly among the finest (and most provocative) examples of Chinese constitutional history of the last decade, these works display a growing sense of theoretical maturity and assertiveness. Despite having different temporal scopes, and despite reaching dramatically different normative conclusions, both books share a common set of theoretical leitmotifs. Apart from their Hobbesian commitment to a strong sovereign state as the logical "premise" of the rule of law, they also share a sociological interest in the processes of elite-integration and consensus-making as tacit conditions of a constitutional polity. Both grapple with China's troubled transition from empire to nation-state and interrogate the persistence of this imperial past in its present rise. Thus, these books have pioneered a methodological turn in Chinese legal historiography that has now gained some prominence outside the niche of sinology, as well, not least due to Su Li's controversial study on China's

Duanhong, Lun xianfa zuowei guojia de genbenfa yu gaojifa [On the Constitution as the Country's Fundamental Law and Highest Law], 20 ZHONGWAi FAXUE [PEKING U. L.J.] 485 (2008); Jiang Shigong, Written and Unwritten Constitutions: A New Approach to the Study of Constitutional Government in China, 36 MoD. CHINA 12 (2010).

${ }^{2}$ The best account is Xu Jilin, Universal Civilization, or Chinese Values? A Critique of Historicist Thought since 2000, in XU JILIN, RETHINKING CHINA’s RISE: A LIBERAL CRITIQUE 61 (David Ownby ed., 2018).

${ }^{3}$ For an early case in point, see CHEN DuANHONG, XIANZHI Yu ZhuQUAN [Constitutionalism AND SOVEREIGNTY] (2007). For a good overview, see Sebastian Veg, The Rise of China's Statist Intellectuals: Law, Sovereignty, and "Repoliticization," 82 CHINA J. 23 (2019).

${ }^{4}$ See Han Liu, Carl Schmitt Redux: Law and the Political in Contemporary Global Constitutionalism, in CARL SCHMITT AND LeO StRAuSs IN THE CHINESE-SPEAKING WorLD: REORIENTING THE POLITICAL 121 (Kai Marchal \& Carl K.Y. Shaw eds., 2017). See generally Xie Libin \& Haig Patapan, Schmitt Fever: The Use and Abuse of Carl Schmitt in Contemporary China, 18 INT'L J. CONST. L. 130 (2020).

${ }^{5}$ See William A. Callahan, Sino-Speak: Chinese Exceptionalism and the Politics of History, 71 J. ASIAN STUD. 33 (2012). 
ancient constitution. ${ }^{6}$ Finally, while clearly demonstrating the analytical potential of "realist" approaches in historical constitutionalism, both books also speak to their more dubious political implications.

Among self-described "conservative liberals" like Gao Quanxi, the intellectual commitment to political realism is the result of a process of critical self-reflection. A professor at Shanghai's Jiao Tong University (until 2016 at Beihang University in Beijing), much of Gao's work in the past decade concerns the question of what it means to be a liberal in an illiberal state. ${ }^{7} \mathrm{He}$ dismisses as naïve the "normative" mainstream in Chinese constitutional scholarship with its emphasis on the "judicialization" of constitutional rights. At the same time, he also rejects the restorative fantasies of Confucian neo-traditionalists and the boastful exceptionalism of neo-statists, leaving him in a somewhat solitary position. ${ }^{8}$ The Road to the Rule of Law in Modern China, co-authored with Tian Feilong (now a professor at Beihang) and Zhang Wei (now a professor in Chongqing), presents both an introduction to Gao's brand of "political constitutionalism" and an ambitious analysis of the vicissitudes of modern Chinese constitutionalism. ${ }^{9}$ Prima facie, the text can be read as an attempt at coming to terms with what the authors call the "tragic fate of constitutional construction" in modern China (at 124).

The first half of the book covers the period from the advent of constitutionalism in the late Qing dynasty to the founding of the People's Republic of China (PRC) in 1949. Using a rather conventional chronology, the authors trace the constitutionalist project from the abortive reform movement of 1898, via the anti-Manchu "racial revolution" of 1911-12, to the subsequent degeneration of liberal republicanism into military factionalism, and finally the rise of first a nationalist and then communist party-state regime since the late 1920s. The second half of the book deals with the fate of constitutionalism under the PRC, from the excesses of Maoism to the post-1978 reform era. There will be many familiar themes for scholars of Chinese legal history in this book, and in some respects it does follow well-trodden paths. However, as we shall see, what makes the text theoretically intriguing is less its "tragic" narrative form than its "realist" conceptual analysis - or, rather, the ambivalent interplay between these two levels of argument.

\footnotetext{
${ }^{6}$ Su Li: The Constitution of AnCIEnt ChinA (Zhang Yongle \& Daniel Bell eds., 2018).

${ }^{7}$ For an excellent overview of Gao's work, see Albert Chen, The Discourse of Political Constitutionalism in Contemporary China: Gao Quanxi's Studies on China's Political Constitution, 14 CHINA REV. 183 (2014).

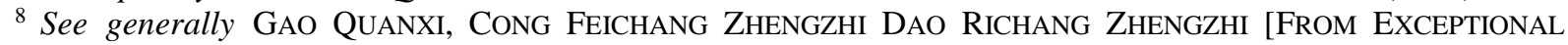

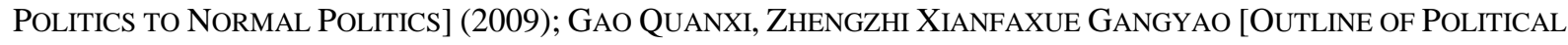
CONSTITUTIONALISM] (2014).

${ }^{9}$ Unfortunately, a partial English version, published in 2015 by Springer, is hardly recommendable due to the poor quality of the translation. See QuANXI GAO, Wei ZHANG \& FEILONG TIAN, THE RoAd to THE RULE OF LAW IN MODERN CHINA (2015).
} 
Reflecting longstanding liberal sensibilities, ${ }^{10}$ the book's surface-level narrative is fairly straightforward: China fell victim to a vicious logic of revolutionary "radicalism"; the repeated frustration of reform initiatives spiraled into ever more radical social blueprints to eradicate the "feudal" remnants of old society, thus moving farther and farther away from the original ideal of a "modern society based on the rule of law" (at 12). Hence, a "healthy" assessment of modern Chinese history needs to reflect on this "revolutionary logic of negation" itself ( $i d$.). What is needed instead is what Gao calls, with intentional ambiguity, a "counter-revolution." Such a counter-revolution does not entail a reversion to the status quo ante; rather, it preserves and operationalizes the revolutionary ideals within a constitutional framework (at 68). In good Hegelian fashion, Gao maintains that all modern revolutions must eventually go through a dialectic movement of "self-negation." Only then can the pre-revolutionary past once more resonate with post-revolutionary society (at 16).

The reconciliation of tradition and modernity has long been a familiar theme in Chinese intellectual discourse. In the post-Mao era, "mainstream" legal scholarship developed a set of narrative strategies to mediate between emotional attachment to Chinese exceptionalism and professional commitment to the language of modern law. In mainstream narratives, the demise of China's traditional world order at the hands of foreign imperialism appears as a violent if ultimately inevitable rupture. Without it, its modernization would have been postponed, perhaps indefinitely. ${ }^{11}$ Conversely, China's premodern polity is treated here with the emotionally sympathetic, but theoretically complacent, attitude of an antiquarian. Overt imperial nostalgia is dismissed as a naïve form of political romanticism. In many ways, Gao et al. adopt this mainstream posture (and its paternalistic overtones). ${ }^{12}$ Although, as a "late-developing state," China's modernization was a response to "Western assault and stimulus" (at 8), modernity itself is nonetheless "a global problem, not a purely Western one" (at 26). At the same time, while rejecting any "straightforward continuity" of its imperial past, they insist that Chinese modernity is "unique" as a result of its exceptionally long and continuous tradition as a

\footnotetext{
${ }^{10}$ See, e.g., QIANFan Zhang, The Constitution of China: A ConteXtual ANalysis 33-7 (2012). For an overview of contemporary discussions about the role of revolutionary radicalism in modern Chinese history, see Rana Mitter, 1911: The Unanchored Chinese Revolution, 208 CHINA Q. 1009 (2011).

${ }^{11}$ The locus classicus is WANG TIEYA, InTERNATIONAL LAW IN ChINA: Historical AND CONTEMPORARY PERSPECTIVES esp. 224 (1990). See also Yang Zewei, Western International Law and China's Confucianism in the 19th Century: Collision and Integration, 13 J. HIST. InT'L L. 285 (2011); Li Zhaojie, The Impact of International Law on the Transformation of China's Perception of the World: A Lesson from History, $27 \mathrm{MD}$. J. INT'L L. 128 (2012).

${ }^{12}$ For an intriguing analysis of mainstream scholarship, see SAMULI SEPPÄNEN, IDEOLOGICAL CONFLICT AND THE RULE OF LAW IN CONTEMPORARY CHINA: USEFUL PARADOXES 104-33 (2016).
} 
"civilizational state." This "profound historical legacy" proved to be both treasure and burden in its quest for modernity; a quest that continues to this day (at 3-5).

Based on these tropes, the book traces the dual forces of revolutionary "radicalism" and conservative "gradualism" through China's twentieth-century transformation. The fiasco of the 1898 reform movement set the stage for all subsequent "radicalization." Following a degrading defeat during the Sino-Japanese War of 1894-5, political reformers around Kang Youwei and his student Liang Qichao quickly realized that military "self-strengthening" was no longer enough. After all, Meiji Japan's constitutional reforms were considered one of the major drivers of its success. In a series of memorials to the throne, Kang and Liang called for far-reaching change, covering not just political and administrative issues, but also, much to the dismay of reactionaries, the traditional educational system and its underlying values. ${ }^{13}$ As is no secret, the reform movement ended in a debacle. When conservatives around empress dowager Cixi staged a coup and put the emperor under arrest, Kang and Liang fled to Japan. Apart from the shortsightedness of reactionaries, Gao et al. maintain, this abject failure was primarily the result of both political "naivety" and exceeding "radicalism" on part of the reformers themselves (at 30-9). Kang and Liang, they suggest, tragically neglected that, for constitutionalism to work, it must be built on genuine elite consensus (a problem that was to resurface violently during the republic). When the Imperial Court finally conceded to constitutional reforms during its last years, it was too little too late, and actually quickened its demise. This missed opportunity of "conservative revolutionary reforms" along the lines of Britain or Japan, the authors suggest, was a historical tragedy and ultimately pushed China down a path of violent revolution (at 51).

A particularly thorny issue was that of ethnicity. While the Qing Court sought to retain legal privileges for the ruling Manchu minority, the rhetoric of Han radicals became increasingly racialized. When an anti-Manchu rebellion broke out in the Han Chinese heartland and resulted in the founding of one of Asia's first republics in 1912, Mongolian and Tibetan elites, with implicit Russian and British backing, swiftly declared their independence from Beijing. Apart from foreign imperialist encroachment, however, it is no coincidence that independence movements broke out in those frontier regions. For the longest part, Mongolia and Tibet had only been loosely integrated into the Qing empire via personal bonds to the Manchu rulers. When the Qing began asserting more immediate forms of territorial sovereignty

\footnotetext{
${ }^{13}$ For the intellectual background of the reformers and the role of the Japanese model, see PETER ZARROW, AFTER EMPIRE: THE CONCEPTUAL TRANSFORMATION OF THE CHINESE STATE, 1885-1924 24-55 (2012).
} 
along its peripheries at the turn of the century, this caused animosity among non-Han elites. ${ }^{14}$ In the eyes of Tibetan leaders, "with the end of imperial rule as embodied in the person of the Manchu emperor, ties between Tibet and its eastern neighbor had ended, rather like a contract that terminates at the deaths of the parties to it." 15 This view was rejected by the republican founding figures who, despite their often explicit Han nationalism, came to consider themselves as natural successors to the Manchu empire in its full territorial expanse. To complicate things further, the concern over territorial disintegration was often couched in a Darwinian language of racial survival, burdening the new republic formally founded on the "unity of five ethnicities."16

Yet there was no political consensus among the Han majority, either. Now, in the revolutionary aftermath, the radical-conservative binary manifested itself anew in the confrontation between southern-based revolutionaries around Sun Yat-sen's nationalist Guomindang and northern Beiyang militarists around the first president (and erstwhile Qing minister) Yuan Shikai. As a representative of the old regime, Yuan had played an ambivalent role in the negotiations leading to the abdication of the infant Qing emperor in February 1912, effectively playing off revolutionaries against monarchists to secure his dominant position under the new order. Despite this tactical maneuvering, Gao considers the imperial abdication edict (逊位诏书) to be a pivotal “constitutional moment." ${ }^{17}$ Based on Gao’s interpretation, the book argues that the edict in fact established a "contractual relationship" to "jointly establish a republic" (at 87). This view, first put forward by the conservative faction around Yuan Shikai, seemed to remedy some of the negative implications of the Han-led revolution for non-Han peoples and thus avoid republicanism being "caught up in the erroneous zone of narrow nationalism" (at 54). From the vantage point of former Qing frontiers, however, it essentially translated "the extensive reach of their [Chinese] emperors into territorial sovereignty claims."18

Ultimately, Gao et al. insist, both revolutionaries and conservatives failed to uphold their obligations under this transitory "constitutional contract." While Sun's Guomindang

\footnotetext{
${ }^{14}$ For a well-balanced account of these processes, see Joseph W. Esherick, How the Qing Became China, in EMPIRE To NATION: HistoriCAL PERSPECTIVES ON THE MAKING OF THE MODERN WORLD 229 (Joseph W. Esherick, Hasan Kayali \& Eric Van Young eds., 2006).

15 Matthew Kapstein, Imperial Directives in the Language of Chö-Yön, in SACRED MANDATES: ASIAN InTERNATIONAL RELATIONS Since CHINGGis KHAN at 116, 119 (Timothy Brook, Michael van Walt van Praag \& Miek Boltjes eds., 2018).

${ }^{16}$ A formidable account of racial sentiments in Han Chinese nation-building is ZARROw, supra note 13, at 14780. See also Maria Adele CARrai, Sovereignty in China: A Genealogy of A ConCEPT Since $184082-94$ (2019).

17 See Gao QuanXi, Lixian Shike: Lun “Qingdi Xunwei Zhaoshu” [Constitutional Moment: On The “ABDICATION EDICT OF THE QING EMPEROR”] (2011).

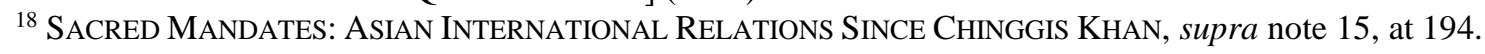


sought to impose its vision of parliamentary supremacy unilaterally, Yuan in turn established a presidential dictatorship, before eventually attempting to restore the monarchy. ${ }^{19}$ Historians of the Chinese republic have long wrestled with the question of who was to fault for this spectacular failure of the new political institutions to effectively channel partisan conflict into constitutionally agreed procedures. Although the book's narrative is tilted in favor of the conservative "constitutionalist faction" which supported Yuan, the authors insist that ultimately both sides displayed a lack of "political maturity" (at 71); both neglected that "the logic of constitution[alism] is inclusive, not exclusionary" (at 133). Hence, Gao et al. reject the usual blame game and anti-Yuan bias in orthodox Chinese historiography. ${ }^{20}$ Beyond Yuan's dictatorial ambitions, they maintain, the deeper structural drivers of the crisis that soon befell the young republic lay in a post-revolutionary power imbalance and the dysfunctionality of the Provisional Constitution (临时约法) in managing it (at 83).

The book's final assessment of the republican revolution, then, is supremely ambiguous. On one hand, the bipartisan consensus brokered in early 1912 "embodied the true conservative spirit of constitutionalism" and amounts to a "Chinese version of the glorious revolution" (at 90). With the exception of Outer Mongolia, which gained de facto independence in the 1920s under Soviet tutelage, the transitory arrangement more or less successfully "preserved" the imperial territory within a new republican form and thus upheld the continuity of China's "legal authority" (法统; id.). For a moment, it thus seemed as though the conservative concerns over territorial continuity and the revolutionary demands for Han Chinese political representation had been successfully reconciled. On the other hand, Gao and his co-authors also suggest that the "radical" character of the revolutionary founding moment effectively sealed the fate of the new state from the onset: "The chaos of the warlord era, the [attempted] restauration of the monarchy, and the emergence of party-states, are but the unfortunate consequences brought about by the radicalism of the Xinhai revolution" (at 58).

What makes their account intriguing, however, is that they introduce another, conceptual layer of analysis which does not neatly overlap with the surface level narrative of steady radicalization. Throughout the book, Gao et al. employ two pairs of conceptual binaries

\footnotetext{
${ }^{19}$ For a good overview of the political history of these years, see Ernest P. Young, Politics in the Aftermath of Revolution: the era of Yuan Shih-K'ai, in 12 THE CAMBRIDGE History OF CHINA: REPUBLICAN CHINA 209 (John K. Fairbank ed., 1983).

${ }^{20}$ This is part of a larger revisionist trend in recent political-legal historiography of the Beiyang period. See, e.g., TANG Qinua, Bei "Feichu Bupingdeng Tiaoyue” Zhebi De BeiYang XiUyue Shi (1912-1928) [TReaty REVISION CAMPAIGN OF THE BEIJING GOVERNMENT, 1912-1928: OUT OF THE SHADOW OF THE “ABROGATION OF UNEQUAL TREATIES”] (2010).
} 
that allow them to distinguish between an underlying state structure and its epiphenomenal political form: Carl Schmitt's distinction between "absolute constitution" and "constitutional law" on the one hand; ${ }^{21}$ and that between "state body" or guoti (国体) and "form of government" or zhengti (政体) on the other. Both of these binaries serve the same analytical purpose of differentiating between foundational and derivative problems of constitutional order. $^{22}$

As Lin Laifan has shown, although the term guoti existed in ancient Chinese sources, as a modern constitutional concept it was first introduced via the Japanese term kokutai, which Meiji-era jurists had developed in a creative reformulation of nineteenth-century German Staatsformenlehre. ${ }^{23}$ Literally translating as "state body" or "body politic," guoti/kokutai was initially used by Japanese authors to determine the locus of sovereignty and projected onto the emperor in a kind of political theology. Unlike guoti, which was thought to be essential and unchanging, zhengti, or "form of government," was considered derivative and epiphenomenal. Thus, while Meiji Japan adopted the political form of constitutional monarchy from Britain and Prussia, its state body had supposedly retained its specifically "Asian" character. ${ }^{24}$ In postrevolutionary China, on the other hand, guoti came to denote the unbridgeable rift separating monarchical and republican "state bodies." Once the guoti had changed, it had changed for good. Remarkably, Gao et al. use the term in the same way: Yuan Shikai's monarchical coup of 1915 failed because it "violated" the republican guoti (at 87).

Previous scholarship on the early republic, the authors contend, overly focused on textual issues of the Provisional Constitution, such as the opposition between presidential and parliamentary "forms of government." From the viewpoint of "political constitutionalism," however, such issues of zhengti "are by no means the foundational questions of the constitution of the Republic of China ... using Carl Schmitt's notion, these are but problems of the 'constitutional law', not the 'constitution'” (at 69). In that sense, the constitutional controversy between conservatives and radicals over presidential and parliamentary powers was merely the epiphenomenal manifestation of a "deep-seated logic buried underneath the [constitutional] text" (at 72). The real problem was that all parties were so consumed by technicalities of the

\footnotetext{
${ }^{21}$ CARl SChMitT, Constitutional TheORy 59ff. (Jeffrey Seitzer trans., Duke University Press, 2008).

${ }^{22}$ See also Ryan Martinez Mitchell, Chinese Receptions of Carl Schmitt Since 1929, 8 PENN. St. J. L. \& INT’L AfF. 181,245 (2020).

${ }^{23}$ Lin Laifan, Guoti gainianshi: kuaguo yizhi yu yanbian [A Conceptual History of guoti: Transnational Transfer and Transformation], 3 ZHONGGUO SHEHUI KEXUE [SOC. SCI. IN CHINA] 65 (2013).

${ }^{24} I d$. at 68 .
} 
"constitutional law" that they neglected the actual act of constitution-making, which requires a unified pouvoir constituant and viable institutional mechanisms of expressing it (at 78).

The question of guoti, or body politic, was brought up once more in the 1940s by no other than Mao Zedong. Now, guoti referred to the underlying class structure of the new socialist state which, in Marxist base-superstructure logic, determined the "formal question of the constitution of political authority" (at 148). Mao, the authors suggest, employed a "political" notion of constitution, not a "normative" one. The communist revolution had created a "political fact in the sense of the 'body politic' [guoti]," and the sole function of the constitutional law was to legalize this factum; it was never intended to be operationalized, let alone judicialized (at 151). Unsurprisingly, then, the common fate of each constitutional law adopted in the following decades was to remain "ornamental" (at 186). They were invariably undercut by a “"political constitution' that tended toward ever greater disorder" (at 143). The infamous 1975 Maoist constitution with its rhetoric of continuous revolution was no deviation from this logic but its "necessary corollary" (at 197).

Predictably, one has to wait until the reform era to see signs of what Gao calls a “counter-revolutionary" tendency. From a legislative perspective, post-Mao reforms had to start from scratch. However, the authors are vigorously opposed to liberal nostalgia about the republican period. Given the constant encroachment by imperialist powers, the "sovereign premise of a modern state was lacking" then; any effort at building constitutionalism was doomed from the onset (at 201). This bleak conclusion contrasts starkly with their somewhat rosy account of post-Mao reforms. ${ }^{25}$ However, it does speak to the book's Hobbesian impetus. In the authors' view, the unprecedented expansion of "societal autonomy" after 1978 (at 203), so dear to Chinese liberals, was premised on the successful political unification under Mao. ${ }^{26}$ Although, to this day, China's Constitution lacks workable mechanisms of enforcement, Gao et al. insist that one must not dismiss it as a mere sham: "The significance of the 1982 Constitution [as a framework for] enlightened rule of law is greater than that of its concrete institutional implementation" (at 202). Liberals tend to neglect that "judicial constitutionalism" is unrealizable under a guoti characterized by party leadership and a zhengti based on democratic centralism (at 228). However, neo-statists too disregard the fact that China's

\footnotetext{
${ }^{25}$ For a more critical Chinese view of the reform period, see ZHANG, supra note 10, at 48-74.

${ }^{26}$ See also $\mathrm{Su} \mathrm{Li}$, supra note 1 , at 48.
} 
epochal socioeconomic transformation is inconceivable outside of the reformist logic of its post-1978 "political constitution" (at 203). Both sides suffer from a conceptual confusion. ${ }^{27}$

Arguably, China's recent political development belies Gao's reformist optimism. ${ }^{28}$ However, the normative tension in his account is theoretical, not empirical. While his liberal commitments lead him to dismiss the principled anti-judicial stance of neo-statists, ${ }^{29}$ his realist convictions also force him to insist on the extrajudicial premises of liberty. For "conservative liberals" like Gao, constitutionalism is but a pipedream without "a stable and continuous sociopolitical basis that in turn rests on a certain structure of authority and guarantee of order" (at 206). The most striking aspect of Gao's thought, then, is neither his liberal anti-radicalism nor his Schmittian conceptual realism, but rather his peculiar method of counterbalancing the two. Perhaps, under China's political status quo, Gao's "liberal Schmittianism” cannot but produce a historical narrative that self-consciously embraces such ideological ambivalence. ${ }^{30}$

While Zhang Yongle's book shares many of Gao's themes, it comes without his liberal and universalist creeds. First published in 2011 and reissued in 2016 in expanded form, The Remaking of an Old Country: 1911-1917 is certain to be among the most significant studies on the constitutional history of early twentieth-century China and its messy transition from empire to nation-state. Like Gao et al., Zhang grapples with the dismal failure of the new republican form to bring about "political integration" in a post-imperial era. His narrative, too, is tilted toward the conservative side of the story. Unlike Gao et al., however, Zhang shows little interest in the liberal niceties of constitutionalism. Echoing $\mathrm{Su} \mathrm{Li}$, he finds it worthwhile to remind his readers of the semantic roots of the term "constitution"- that is, "to constitute." "The initial goal of constitutionalism is to integrate the political community; by no means does it aim at dividing the political community for the sake of "limited government"” (at 17). This is more than semantic politics, of course. Through his innovative rereading of conservative intellectuals like Kang Youwei and Liang Qichao, Zhang's book also gives striking insights into the nexus between statism and historicism in contemporary Chinese legal discourse.

\footnotetext{
${ }^{27}$ Some statists deny that China's "absolute constitution" has changed at all since 1949. Cf. Zhao Xiaoli, History, Culture, Revolution, and Chinese Constitutionalism, in Su LI: THE CONSTITUTION OF ANCIENT CHINA, supra note 6, at 198, 205.

${ }^{28}$ For a critical account, see Jerome Cohen, Law's Relation to Political Power in China: A Backward Transition, 86 SoC. RES. 231 (2019); for a more optimistic account, see Taisu Zhang, Tom Ginsburg, China's Turn Toward Law, 59 VA. J. INT'L L. 306 (2019).

${ }^{29}$ See Gao Quanxi, Xianfa de shengming zaiyu shishi [The Life of the Constitution Resides in its Implementation] 170 MinZHU YU KEXUE [DEMOCRACY \& SCI.] 6 (2018).

${ }^{30}$ See further Lucas Brang, Carl Schmitt and the Evolution of Chinese Constitutional Theory: Conceptual Transfer and the Unexpected Paths of Legal Globalisation, 9 GLOBAL CONST. 117, 145ff. (2020).

${ }^{31} \mathrm{Su} \mathrm{Li}$, Introduction, in SU LI: The CONSTITUTION OF ANCIENT ChINA, supra note 6, at 16, 16.
} 
In his review of Wang Hui's The Rise of Modern Chinese Thought, Zhang neatly captured the intellectual project that many in his generation of Chinese intellectuals have chosen to pursue: "the search for the 'seeds' of an alternative modernity, distinct from that of the West and capable of avoiding its ailments, in intellectual legacies of the long Chinese past." 32 Trained as a political scientist at University of California Los Angeles before becoming a professor of law at Peking University, Zhang is part of a younger generation that he himself recently described as an "intellectual independence movement" and the "carriers of a cultural confidence that the Chinese are capable of finding the path and institutions best suited for themselves." 33 A seminal figure in this project is the "New Left" historian Wang Hui. Apart from contributing a lengthy preface to Zhang's book, Wang's work has been instrumental in the statist-historicist turn of recent years. ${ }^{34}$ Not only has he eloquently dismantled Orientalist prejudices against "Asian" imperial forms in Western intellectual history. Wang also put forward the continuity of China's imperial form as a juridical question: How is it that, "in the twenty-first century, China is the only society in the world that, as a sovereign state and nation, has retained the territorial area, population, and political culture that it inherited from an empire that existed before the nineteenth century?"35

Zhang sets out to explain this "world-historical miracle" (at 1). Covering the period from the 1911 revolution to the failed attempts at restoring the monarchy in the years 1915 to 1917, his account is set against a watershed in both Chinese and global history: the implosion of all major Eurasian empires from Peking and St. Petersburg to Vienna and Constantinople. This naturally results in a denser and more richly textured account than the macro-history of Gao et al. Using the notion of "composite monarchies," the book asks how various forms of indirect and differential rule intersected in the imperial constitution of these multi-ethnic states (and lived on after their demise). This echoes developments in the school of historiography known as "New Qing History" (although Zhang, like Gao, is somewhat ambivalent about its critical implications for Han Chinese nation-building). As this scholarship has shown, the Qing state was characterized by legal pluralism and ethnicity-based discrimination and built upon personal ties between Manchu rulers and other non-Han religious elites in frontier regions. ${ }^{36}$

\footnotetext{
${ }^{32}$ Zhang Yongle, The Future of the Past, 62 NEW LEFT REV. 47, 48 (2011).

${ }^{33}$ Zhang Yongle \& Daniel Bell, Editors' Introduction to Su LI: ThE Constitution of ANCIENT ChINA, supra note 6 , at $1,14-15$.

${ }^{34}$ For a recent example, see Wang Hui, Zuowei sixiang duixiang de ershi shiji zhongguo (xia): kongjian geming, hengxiang shijian yu zhihuan de zhengzhi [Twentieth-Century China as an Object of Thought (Part Two): Spatial Revolution, Horizontal Time, and the Politics of Replacement], 6 KAIFANG SHIDAI [OPEN TIMES] 56 (2018).

${ }^{35}$ WANG HuI, CHINA FROM EMPIRE TO NATION-STATE 27 (2014).

${ }^{36}$ For a good overview, see Evelyn S. Rawski, Presidential Address: Reenvisioning the Qing: The Significance of the Qing Period in Chinese History, 55 J. ASIAN STUD. 829 (1996); for Qing legal pluralism, see PÄR KRISTOFFER
} 
The Manchu emperor was not only "Son of Heaven" within Confucian political cosmology; he also claimed the title of "Great Khan" vis-à-vis Mongolians, and was recognized by Tibetan religious authorities as the incarnation of the bodhisattva Manjusri. This not only means that the emperor possessed different ritual "bodies," as Zhang points out (at 217). Arguably, it also implies, as one study recently claimed, that the Manchu empire incorporated distinct regional "systems of international law" into a single but differentiated state. ${ }^{37}$

Administratively, this dualism manifested in what Zhang describes as two separate institutional logics and channels of "elite integration": one vertical and meritocratic, best embodied in the imperial examination system operating in the Han Chinese heartland; the other horizontal and aristocratic, using an elaborate system of hereditary titles to "co-opt" the nobility in central Asian frontier regions (esp. at 208). As Su Li suggests, imperial China's "cultural constitution" thereby mediated performance-based elite-selection with a concern for ethnic and geographic "representation," resulting in an intricate "equilibrium among different areas within China's territory and among the interests of different ethnic groups and peoples." ${ }^{38}$ However, studies also show how the late nineteenth-century "indigenization" of European international law caused this loosely integrated and bifurcated structure to be gradually superseded by an outward expansion of territorial governance to peripheries and a Han Chinese "civilizing mission within." 39 Seen in this light, modern Chinese state-building is characterized by a paradox: it was both anti-imperialist (in its resistance to Western powers and Japan) and quasicolonial (in its more or less forceful incorporation of former Qing frontiers into a centralized and Han-dominated nation-state). ${ }^{40}$

Although the Qing empire was the first among the old Eurasian empires to fall, it was the only to evade the fate of territorial disintegration by the centrifugal forces of nationalism. According to Zhang, the main reason for this counterintuitive outcome was its relative

\footnotetext{
CASSEl, Grounds OF JUdGEMENT: EXTRATERritoriAlity AND IMPERIAL POWER IN NiNETEENTH-CENTURY CHINA AND JAPAN 15-29 (2012).

${ }^{37}$ SACRED MANDATES: Asian InTERnATIONAl RELATIONS SinCE ChINGGis KHAN, supra note 15, at 8-12.

${ }^{38} \mathrm{Su}$ Li, Scholar-Officials, in Su LI: The CONSTITUTION OF ANCIENT CHINA, supra note 6, at 98, 133.

${ }^{39}$ For the Tibetan case, see Scott Relyea, Indigenizing International Law in Early Twentieth-Century China: Territorial Sovereignty in the Sino-Tibetan Borderland, 38 LATE IMPERIAL CHINA 1, esp. 39 (2017); for Taiwan and Xinjiang, see Lin Xuezhong, Cong Wanguo Gongfa DaO Gongfa WaijiaO: Wanqing Guojifa De Chuanru, Quanshi Yu Yingyong [From Public LaW of Nations to Public LaW Diplomacy: The INTRODUCTION, INTERPRETATION, AND APPLICATION OF INTERNATIONAL LAW IN LATE QING CHINA] 272-5 (2009); for a comparative perspective, see Richard S. Horowitz, International Law and State Transformation in China, Siam, and the Ottoman Empire during the Nineteenth Century, 15 J. WorLd HIST. 445, 475-84 (2004).

${ }^{40}$ See Maria Adele Carrai, Learning Western Techniques of Empire: Republican China and the New Legal Framework for Managing Tibet, 30 LEIDEN J. INT'L L. 801 (2017). For the conceptual difficulties of applying terms like "imperialism" and "colonialism" to the Qing empire's territorial expansion, and Chinese criticism of the New Qing History more generally, see Leigh K. Jenco \& Jonathan Chappell, Overlapping Histories, Coproduced Concepts: Imperialism in Chinese Eyes, 79 J. ASIAN STUD. 685 (2020).
} 
geopolitical distance from the European system of fierce inter-state competition (at 43). Moreover, anticipating Su Li's work on the emperor's constitutional function, ${ }^{41}$ Zhang also suggests that the legal institution of universal emperorship exerted a decisive integrating effect, even beyond China proper: "under the Sinocentric tribute system, the 'emperor' by no means belonged to the exclusive authority of the Han Chinese ..." (p. 47). Consequently, like Gao, Zhang puts great emphasis on the legal status of the emperor's abdication which, despite claims to statehood by Tibetans and Mongolians, secured the relatively smooth transfer of sovereignty from empire to republic: "The edict demonstrated that the sovereignty wielded by the Qing Court and the Republican government was that of the same China" (at 4). Moreover, Zhang argues that there was a tacit understanding among the entire political elite, including antiManchu radicals, that a swift transition was needed to avoid intervention by the imperialist powers (at 55).

Zhang describes this transitory constitutional arrangement as a "great compromise"(大 妥协). Reflecting the new statist paradigm in Chinese jurisprudence, he rejects the negative views of this "compromise" in traditional Marxist historiography, which decried it as a mere concession to the ancien régime. For Zhang, the compromise's overriding value was that it served as a "juridical basis" to rebut claims to statehood by ethnic minorities in subsequent decades (at 61). Furthermore, it demonstrated that the republic had not emerged ex nihilo. Like other scholars of his generation, ${ }^{42}$ Zhang vows to bridge the institutional rift supposedly separating the Chinese world before and after 1912 (or 1949, for that matter). These political ruptures did not occur in "empty space"; nor did they simply sever the old imperial "legal normativity" (at 63). China's imperial constitution did not stop operating in 1912.

The ambiguous role of the Qing emperor's abdication in the founding of the republic gave rise to two competing narratives of its legal basis. Southern revolutionaries followed an American "bottom-up" model: the central provinces that had seceded from the Qing ought to form a new state on a common Rousseauian basis. This view, Zhang suggests in line with Gao, displayed a short-sighted Han nationalism and caused unnecessary anxiety among non-Han elites on the periphery (at 64-5). As mentioned above, the northern Beiyang faction around president Yuan Shikai followed a different logic. Yuan's legal advisor, the Japanese jurist Aruga Nagao, conceptualized the abdication edict as a contractual transfer of "the right to rule"

\footnotetext{
${ }^{41} \mathrm{Su} \mathrm{Li}$, Zuowei zhidu de huangdi [The Emperor as an Institution], 12 FALÜ HE SHEHUI KeXUE [LAW \& SOC. SCI.] 153 (2013).

${ }^{42}$ Cf. Liu Han, The Symbolic and the Functional: Su Li on the Constitution of Ancient China, in SU LI: THE Constitution OF ANCIENT CHINA, supra note 6, at 177, 189.
} 
(统治权) from monarch to people. In his view, the juridical basis of the new republic lay in this act of transferal — not in the elusive pouvoir constituant of the people (at 68-9). Irritatingly, this seemed to imply that the sovereignty of the new state was subject to "contractual" limitations set by the Manchu Court (at 73). For republican jurists like Dai Jitao or Wang Chonghui, this reading was hard to swallow. After all, the pouvoir constituant was by definition unrestrained and non-derivative (at 78-9).

In the end, yielding to disparities in military power, the revolutionaries consented to the terms set by the "compromise" (although its constitutional status and the favorable treatment it granted to the Imperial Court remained highly contested, at 84-5). Yuan Shikai was elected as president by the provisional parliament in Nanjing and in turn formally endorsed the popular base of his authority. As Zhang puts it succinctly: "From a legal perspective, the northern government was incorporated by the southern government; but from the perspective of actual political power, the southern government was absorbed by the northern government ..." (at 4). However, like Gao et al., Zhang's view of the compromise is highly ambiguous. While securing the territorial continuity of the empire, it also "planted the seeds for the failure of constitutionalism in the early republic" (at 9). Indeed, the two narratives regarding the juridical basis of the republic continued to structure the ensuing controversy over parliamentary and presidential powers. While the revolutionaries sought to hollow out Yuan's powers as president, he responded by dissolving first the Guomindang and then the parliament itself. Zhang, too, insists that this crisis was not contingent; it was implied in the structure of the "great compromise" itself (at 171).

In what is the most intriguing part of the book, Zhang combines a Schmitt-informed reading of "statist" intellectuals Kang Youwei and Liang Qichao with an unforgivingly realist dissection of the republican constitutional order. Upon encountering authors like Johann Caspar Bluntschli and Conrad Bornhak while in Japanese exile, Liang and Kang gradually abandoned their belief in Rousseauian contractualism. ${ }^{43}$ Now, they found the locus of sovereignty no longer in the people, but in the state itself, which they came to conceive as an "organism," "44 simultaneously standing above society and integrating it (at 106-12). However, mirroring Su Li's argument about the imperial examination system as a constitutional institution, ${ }^{45}$ Zhang argues that its abolition in 1905 had resulted in the irreversible disintegration of local gentry

\footnotetext{
${ }^{43}$ For an excellent account of Liang's and Kang's turn to "statism," see ZARROW, supra note 13, at 104-17.

${ }^{44}$ For the use of organic imagery in contemporary Chinese legal discourse, see Lucas Brang, The Dilemmas of Self-Assertion: Chinese Political Constitutionalism in a Globalized World, MoD. CHINA (forthcoming 2021).

${ }^{45} \mathrm{Su} \mathrm{Li}$, Ancient China's Cultural Constitution: A Unified Script and Mandarin Chinese, in SU LI: THE CONSTITUTION OF ANCIENT CHINA, supra note 6, at 66, esp. 94.
} 
elites and an overall "fragmented society" (at 126). Despite their laudable realism, then, Kang and Liang neglected this lack of a social basis for Prussian-style political integration through the state in post-monarchical China (at 125). Ultimately, their hopes for Yuan Shikai to fill this post-imperial void through top-down administrative unification were in vain (at 190).

Following Carl Schmitt's analysis of nineteenth-century German state theory, Zhang suggests that the real function of Kang's and Liang's "doctrine that sovereignty resides in the state” (主权在国论) was purely “dilatory” (at 114). Upon closer examination, the "great compromise" thus turns out to be a mere "dilatory formal compromise" for the sake of territorial unity. Rather than Gao's "glorious revolution," it was but a temporary suspension of the Schmittian question of who decides upon the state of exception (at 172). Yet, as Schmitt famously wrote, "[e]very genuine conflict reveals the simple either/or of the mutually exclusive principles of political form. ${ }^{" 46}$ Zhang endorses this dictum. Indeed, his merciless exposure of the Provisional Constitution's structural contradictions (at 133-6) is reminiscent of Schmitt's conceptual disassembling of the Weimar Constitution. ${ }^{47}$ A conceptual realist par excellence, Zhang suggests that the ultimate reason for the failure of republicanism was that the "constitutional law" imposed on Yuan by a Guomindang-controlled parliament was not in line with the "absolute constitution" of the post-imperial order (at 173-4). If Gao's nemesis is "radicalism," Zhang's is "formalism": the insurmountable divergence between legal stipulation and actual power (at 180). Hence, the "tragedy" of these years is that they unveil how "legal documents" cannot create genuine "elite consensus," and sometimes even undermine it (at 18).

The political implications of Zhang's narrative are far-reaching. Essentially, he suggests that territorial unity (the "great compromise" of 1912) was bought with the preordained failure of parliamentary democracy (the "great rupture" of 1913). He considers this to be a necessary trade-off. This is not the crux of the story, however. Above all else, he implies the "historical logic of the subsequent rise of Leninist state-parties" (at 128). Unlike Gao, Zhang welcomes this outcome. After all, only a socialist revolution could genuinely integrate both the Chinese heartland and periphery (at 238). Only the party-state could bring an end to decades of political disintegration and free the people from the plights of warlordism and separatism (at 275). If this

\footnotetext{
${ }^{46}$ SCHMITT, supra note 21, at 105.

47 For Schmitt's conceptual realism, see Otto Kirchheimer, Bemerkungen zu Carl Schmitts "Legalität und Legitimität” [Remarks on Carl Schmitt's “Legality and Legitimacy”], in VON DER WEIMARER REPUBLIK ZUM FASCHISMUS: DIE AUFLÖSUNG DER DEMOKRATISCHEN RECHTSORDNUNG [FROM THE WEIMAR REPUBLIC TO FASCISM: THE DisSOLUTION OF THE DEMOCRATIC LEGAL ORDER] 113 (Wolfgang Luthardt ed., 1976).
} 
required forced incorporation of de facto self-governing territories, so be it. ${ }^{48}$ While his erudition and analytical sharpness are beyond doubt, normatively, Zhang's historical narrative amounts to little more than an ex post rationalization of China's political status quo.

Recent events indicate that China's post-imperial "integration" is more frail than Zhang would seem to admit. To be sure, the ease with which he brushes aside non-Han demands for self-determination as entirely elite-driven, instigated by foreign imperialists, and lacking any genuine popular basis, is nothing new (at 49). Predictably, he insists that only the communist party succeeded in rooting out the social basis of separatism by toppling religious elites and garnering popular support (at 57). Counterexamples like the Tibetan uprising of 1959 are dismissed as being orchestrated by "upper-class aristocrats" (id.). With no word does Zhang mention that the events in Lhasa were preceded in 1958 by another large-scale rebellion of the Muslim and Tibetan population in Qinghai province, which was linked to forced collectivization and policy-induced famine. ${ }^{49}$ Today, central authority along China's unruly peripheries is once more exerted through means of cultural-linguistic assimilation (most recently in Inner Mongolia), or even downright repression (most abhorrently in Xinjiang). ${ }^{50}$ Given these developments, the book's self-congratulatory claim about the popular basis of the party-led integration of inherited Qing territory rings hollow.

Perhaps the greatest challenge to Chinese central authority, and a cataclysmic event for jurists of Zhang's generation, has been the rise of localism in Hong Kong. Indeed, even former liberals like Gao's co-author Tian Feilong now endorse hardline nationalist policies. ${ }^{51}$ In his chapter-length discussion of how Yuan Shikai recycled some of the "ancient techniques of imperial rule" for his "co-optation" of frontier elites, subsequently added to the 2016 edition of the book, Zhang explicitly uses the phrase "one country, two systems" (at 219). This is no casual pun; nor is Zhang alone with such imperial presentism. ${ }^{52}$ This rhetoric indicates that, for

\footnotetext{
${ }^{48}$ For the "peaceful liberation" of Tibet and Xinjiang, see DILEMMAS OF VICTORY: THE EARLY YEARS OF THE PeOPlE’s RePUblic OF ChINA chs. 6, 8 (Jeremy Brown \& Paul G. Pickowicz eds., 2010).

${ }^{49}$ For the political impact of the Great Leap famine on minority areas in Qinghai, Gansu, and Sichuan, see FELIX WEMHEUER, A SOCIAL History OF MAOIST CHINA 152-7 (2019).

${ }^{50}$ For a genealogy of this turn in "united front" policy, see James Leibold, The Spectre of Insecurity: The CCP's Mass Internment Strategy in Xinjiang, 59 CHINA LEADERSHIP MONITOR (Mar. 1, 2019), https://www.prcleader.org/leibold.

${ }^{51}$ See Chris Buckley, "Clean Up This Mess": The Chinese Thinkers Behind Xi's Hard Line, N.Y. TIMES (Aug. 2 , 2020), https://www.nytimes.com/2020/08/02/world/asia/china-hong-kong-national-security-law.html.

${ }^{52}$ Cf. Su Li, The Constitution of the Territory and Politics of a Large State, in SU Li: THE CONSTITUTION OF ANCIENT CHINA, supra note 6, at 33,60.
} 
Chinese neo-statists, current Beijing-Hong Kong relations should be viewed through the lens of China's persisting imperial constitution and its Janus-faced state body. ${ }^{53}$

For Zhang, Yuan's revival of imperial symbolism was a necessary if ultimately failed attempt at adopting the "ritual role" of the "emperor's body" (at 217). Other Chinese Schmittians now unabashedly call for a "political theology" of party leadership to fill this postimperial void. Liu Han, for instance, demands that one must "link the emperor to the party in the political imagination to ground the legitimacy of the rule." ${ }^{54}$ Zhao Xiaoli, too, insists that knowing the constitution of imperial China is "an inherent demand of the rationality of the Constitution of the People's Republic of China." 55 In many of these recent writings, Hobbesian statism, Schmittian conceptual realism, and Chinese historical exceptionalism form a peculiar alliance. Whatever their concrete motivation, it seems abundantly clear that the selective recycling of China's imperial past for present political purposes has just begun.

\footnotetext{
${ }^{53}$ For an explicit argument linking China's imperial past and the PRC's Hong Kong policy, see JIANG SHIGONG, ChinA's Hong Kong: A PoliticAl AND Cultural PersPeCtive 128-34 (2017).

${ }^{54}$ Liu, supra note 42, at 189.

${ }^{55}$ Zhao, supra note 27, at 198.
} 